\title{
Neocyclops (Protoneocyclops) ferrarii, a new species of cyclopid (Copepoda: Cyclopoida) from Belize, with remarks on the morphology of the genus Neocyclops
}

\author{
Carlos Eduardo Falavigna da Rocha \\ Departamento de Zoologia, Instituto de Biociências, Universidade de São Paulo, Caixa Postal 11294, \\ 05422-970 - São Paulo, SP, Brazil
}

Keywords: Taxonomy, Crustacea, Copepoda, Cyclopoida, Neocyclops, Caribbean fauna, Belize, brackish water

\begin{abstract}
Neocyclops (Protoneocyclops) ferrarii sp. n. is described from Candy's Pond, Twin Cays, Belize. It is morphologically closest to $N$. (P.) wellsi Petkovski, 1986 from Mozambique and $N$. (P.) herbsti Petkovski, 1986 from the Red Sea.

Pediger 1 in Neocyclops is distinct although reduced and often concealed beneath the cephalic shield. Specimens of Neocyclops (N.) vicinus and $N$. (N.) medius showed the same condition, warranting the supposition that the free pediger 1 is a consistent feature of the genus. The genital double somite bears a transverse cuticular thickening which apparently supports the seminal receptacle. The importance of the integumental pore patterns of the urosome and legs as useful taxonomic characters is pointed out.
\end{abstract}

\section{Zusammenfassung}

Neocyclops (Protoneocyclops) ferrarii sp. $\mathrm{n}$. ist zum ersten Mal für Candy's Pond, Twin Cays, Belize beschrieben worden. Die Art ist $N$. (P.) wellsi Petkovski, 1986, aus Mosambik, und $N$. $(P$.$) herbsti Petkovski, 1986, aus dem Roten Meer, am nächsten.$

Pediger 1 in Neocyclops zeigt sich immer noch deutlich obwohl verkleinert und oft unter dem Kopfschild versteckt. Untersuchte Individuen von Neocyclops $(N$.$) vicinus und N$. (N.) medius zeigten dieselbe Kondition und rechtwertigen die Annahme dass der freie Pediger 1 ein beständiges Kennzeichen des Genus ist. Das doppelte Genitalsomit hat eine transversale Kutikularverdickung die offensichtlich das Receptaculum seminis stützt. Die Bedeutung des Musters der Hautporen des Hinterkörpers und der Beine als nützliche taxonomische Merkmale ist angeführt.

\section{Introduction}

The first record of the genus Neocylops from the Caribbean region is that of Pleşa (1973), who described $N$. improvisus from the interstitial of a sandy beach in Cuba. Subsequently, Pesce (1985) described Neocyclops (Protoneocyclops) stocki from Bonaire and identified specimens from San Salvador Island, Bahamas, as Neocyclops (Neocyclops) affinis Dussart, 1974, despite some morphological differences from the type material collected at the coast of Ethiopia. Petkovski (1986) redescribed $N$. (P.) stocki based on material from San Andrès Island and Bermuda, attributing to this species the Cuban specimens identified as $N$. remane $i$ mediterraneus (Kiefer, 1960) by Pleşa (1981). Recently, Pesce \& Galassi (1993) increased the number of species in the West Indies to seven, describing $N$. $(P$.$) geltrudeae as a new species from Curaçao,$ recording $N$. (N.) medius Herbst, 1955 in Tortuga, Bonaire, Blanquilla, Los Roques, and Margarita, $N$. (N.) vicinus (Herbst, 1955) in Los Roques and Jamaica, $N$. (P.) stocki in Bonaire and Curaçao as well as communicating Fiers' record of $N$. (P.) papuensis Fiers, 1986 in the Bahamas.

\section{Habitat}

Candy's Pond, Twin Cays, is about $5 \mathrm{~m}$ in diameter, $2 \mathrm{~m}$ deep, and heavily shaded by mangroves. At the time of collecting, a sharp thermocline and halocline were present at about 20-30 $\mathrm{cm}$. The upper water was $30^{\circ} \mathrm{C}, 19 \% \mathrm{~S}$ and the deeper water $35^{\circ} \mathrm{C}, 39 \% \mathrm{~S}$. The copepods were collected above leaf litter at the bottom of the pond (F. Ferrari, pers. comm.). Accompanying species: Apocyclops panamensis (Marsh, 1913). 


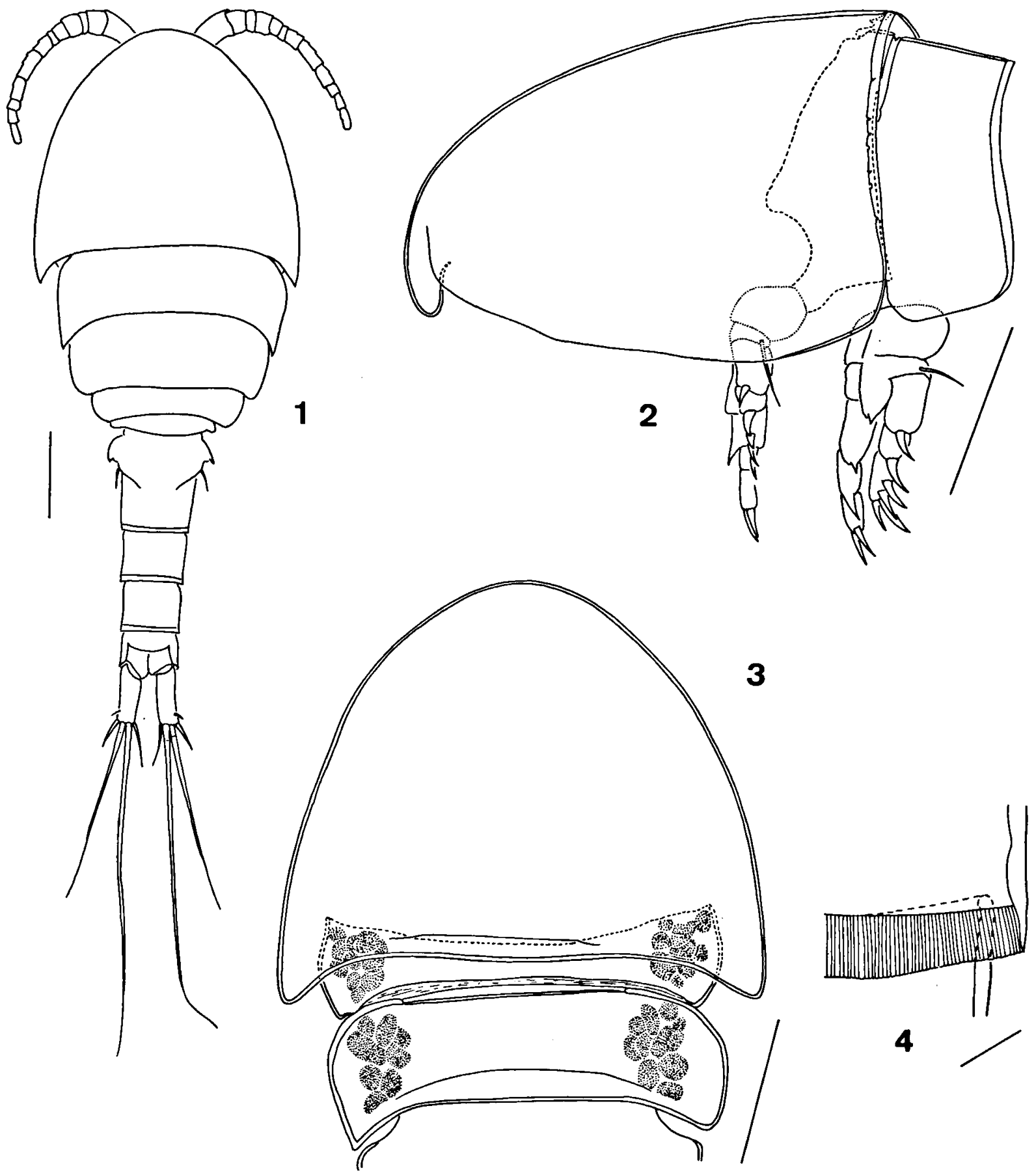

Figs. 1-4. Neocyclops (Protoneocyclops) ferrarii sp. n., ९: 1, habitus, dorsal; 2, anterior part of prosome showing pediger 1 concealed beneath carapace-like extension of the cephalic shield, lateral; 3, anterior part of prosome showing pediger 1 partly exposed, dorsal (dotted areas representing muscle insertions); 4 , hyaline frill of posterior border of pre-anal somite, ventral. Scale bars $100 \mu \mathrm{m}$ (Figs. 1-3), $10 \mu \mathrm{m}$ (Fig. 4). 

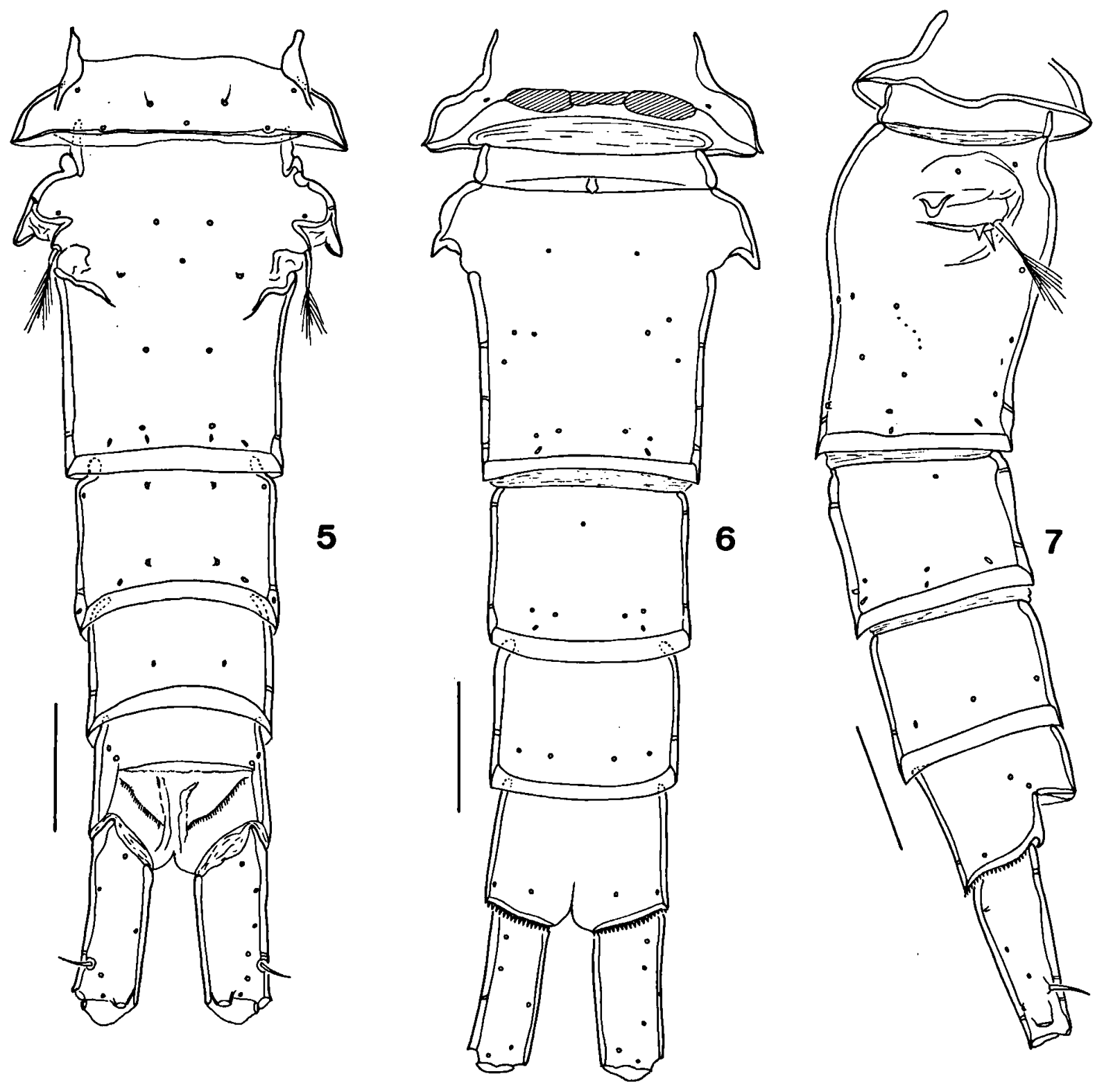

Figs. 5-7. Neocyclops (Protoneocyclops) ferrarii sp. n., ९: 5, urosome, dorsal; 6, urosome, ventral; 7, urosome, lateral. All figures showing integumental pore patterns as visible in respective views. Scale bars $50 \mu \mathrm{m}$.

\section{Methods}

Whole specimens were examined in temporary lactic acid mounts. Fragments of cover glass were used to support the cover glass of the preparations. By moving the cover glass slowly and carefully by hand, the whole animal or a particular appendage was placed in different positions, making possible observation of morphological details. After examination the specimens were preserved in $70 \%$ ethanol.
The urosome integumental pore pattern was obtained from clean exoskeletons of two females found in the sample.

Dissected and intact specimens were examined for variation in the characters described.

The figures were made using an oil immersion lens and a camera lucida on a Leitz Laborlux $D$ phase-contrast microscope.

The material is deposited in the National Museum of Natural History, Smithsonian Institution, Washington (NMNH, formerly USNM) and the Museu de Zoologia of the Universidade de São Paulo, São Paulo (MZUSP). 


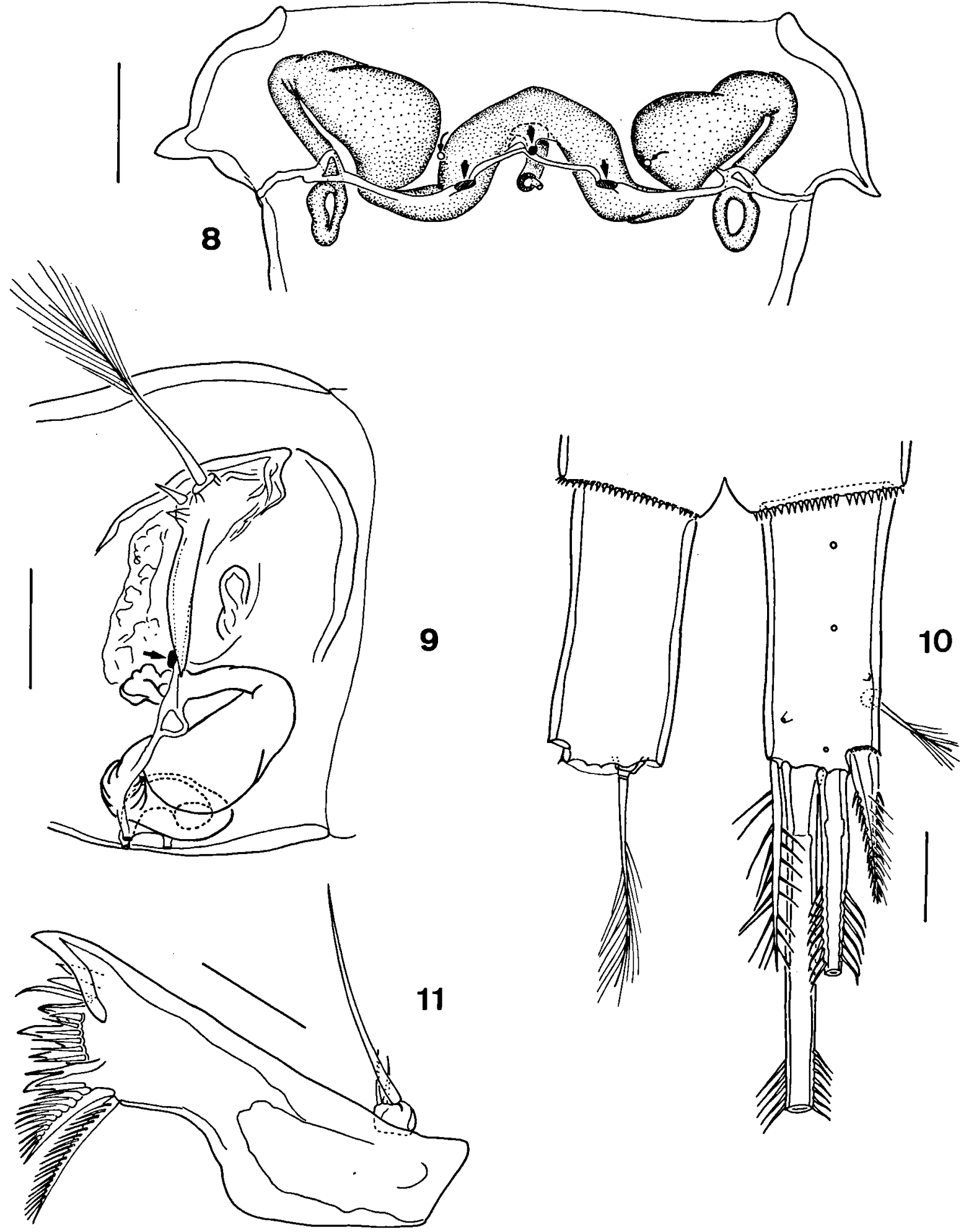


Descriptive part

Neocyclops (Protoneocyclops) ferrarii sp. n.

(Figs. 1-19)

Material examined. - Belize, $36 \%$ $\% 150^{\circ} 0^{\circ}$ and 24 copepodids from Candy's Pond, Twin Cays $\left(16^{\circ} 50^{\prime} \mathrm{N}, 8^{\circ} 5^{\prime} \mathrm{W}\right), 3$ July 1987, F.D. Ferrari coll. Female holotype (USNM 259772) and 15 paratypes (USNM 259773) in NMNH; 59 paratypes in MZUSP (coll. nr. 11571).

Description. - Female: Body length, excluding caudal setae, 635 to $860 \mu \mathrm{m}(n=9)$. Prosome little longer than urosome $(1.18-1.3: 1)$. First pediger narrower than second pediger and concealed beneath carapace-like extension of posterior margin of dorsal cephalic shield (Figs. 1-2); only one specimen had this somite partly exposed (Fig. 3). Hyaline fringes of posterior borders of prosomites, genital double somite and 2 subsequent urosomites striated (Fig. 4). Pore signature pattern of urosome (Figs. 5-7) consisting of circular and slit pores.

Genital double somite (Fig. 5) about as long as wide and with lateral expansions bearing spiniform projections at first third. Seminal receptacle (Fig. 8) turning backward from connection with copulatory duct, then expanding and curving onward and outward after straightening about midway along its length; short receptacle ducts present, connecting both expanded parts to dorsolateral genital antra. Transverse cuticular thickening partially fused to seminal receptacle on both sides anteriad to its straightening, linked to integument of genital double somite by 3 ventral attachment areas (straight arrows in Fig. 8) and another attachment area very near ventral tip of opercular plate of each leg 6 (arrows in Fig. 9). Copulatory area with pair of integumental pores (curved arrows in Fig. 8).

Anal somite (Figs. 5-7) bearing ventrolateral row of spinules along posterior margin. Anal operculum consisting of narrow, finely crenulate hyaline membrane.

Caudal rami (Figs. 5-7, 10) about 3 times longer than wide $(n=9)$. Outermost apical seta spine-like, ornamented with row of spinules on both inner and outer margins and longitudinal row of setules on dorsal and ventral sides. Innermost apical seta 1.4 times longer than outermost apical seta and bearing stiff setules. Middle apical setae with stiff short setules proximally, setules becoming gradually longer and thinner towards tip. Dorsal seta as long as innermost apical seta.

Antennule 12-segmented. Setal armature as follows: $8,4,2,6,4,2,2,3,2,2,2,7$. Aesthetasc on segments 9, 11, and 12 .

Antenna 5-segmented. Coxa very reduced and unarmed. Basis with 2 inner setae and outer seta (exopodite) reaching apex of terminal segment. Endopodite segments $1-3$ spinulose on outer margin and with 1,5 , and 7 setae, respectively.

Labrum with 9 median denticles flanked by row of short spinules along free margin and 2 rows of long spinules on ventral surface.

Mandible (Fig. 11) reduced to coxa with gnathobase and short palp bearing 3 setae.

Maxillule consisting of powerful praecoxa (Fig. 12) and 2-segmented palp (Fig. 13). Praecoxal arthrite armed with 3 spines fused to segment and 1 articulated spine on distal margin and 7 elements on inner surface. Proximal segment (basis) of palp armed with 3 inner setae and 1 outer seta (exopodite). Distal segment (endopodite) reduced, armed with 3 setae.

Maxilla 4-segmented. Praecoxa fused to coxa on posterior surface. Setal formula: 2, 3, 3, 5 .

Maxilliped 4-segmented. Setal formula: 3, 2, $2,3$.

Legs 1-4 armed as follows (Roman numerals representing spines; Arabic numerals indicating setae):

\begin{tabular}{|c|c|c|c|c|c|c|c|}
\hline \multicolumn{2}{|c|}{ Coxa Basis } & \multicolumn{3}{|c|}{ Exopodite } & \multicolumn{3}{|c|}{ Endopodite } \\
\hline & & 1 & 2 & 3 & 1 & 2 & 3 \\
\hline Leg $10-1$ & $1-I$ & \multicolumn{3}{|c|}{ I-1; I-1; III,2,3 } & \multicolumn{3}{|c|}{$0-1 ; 0-2 ; I, I+1,3$} \\
\hline Leg $20-1$ & $1-0$ & \multicolumn{3}{|c|}{ I-1; I-1; III,I + 1,4 } & \multicolumn{3}{|c|}{$0-1 ; 0-2 ; 1,11,3$} \\
\hline Leg $30-1$ & $1-0$ & \multicolumn{3}{|c|}{ I-1; I-1; III,I + 1,4 } & \multicolumn{3}{|c|}{$0-1 ; 0-2 ; 1,11,3$} \\
\hline Leg $40-1$ & $1-0$ & \multicolumn{3}{|c|}{$\mathrm{I}-1 ; \mathrm{I}-1 ; \mathrm{II}, \mathrm{I}+1,4$} & \multicolumn{2}{|c|}{ 0-1; } & $\mathrm{I}, \mathrm{II}, 4^{*}$ \\
\hline
\end{tabular}

- Endopodite segments 2 and 3 of leg 4 fused.

Figs. 8-11. Neocyclops (Protoneocyclops) ferrarii sp. n., ९: 8, seminal receptacle, ventral (straight arrows indicating attachment areas of transverse cuticular thickening to integument of genital double somite; curved arrows indicating integumental pores); 9, seminal receptacle, lateral (meaning of straight arrow as in Fig. 8); 10, caudal rami, ventral; 11, mandible, inner. Scale bars $20 \mu \mathrm{m}$. 

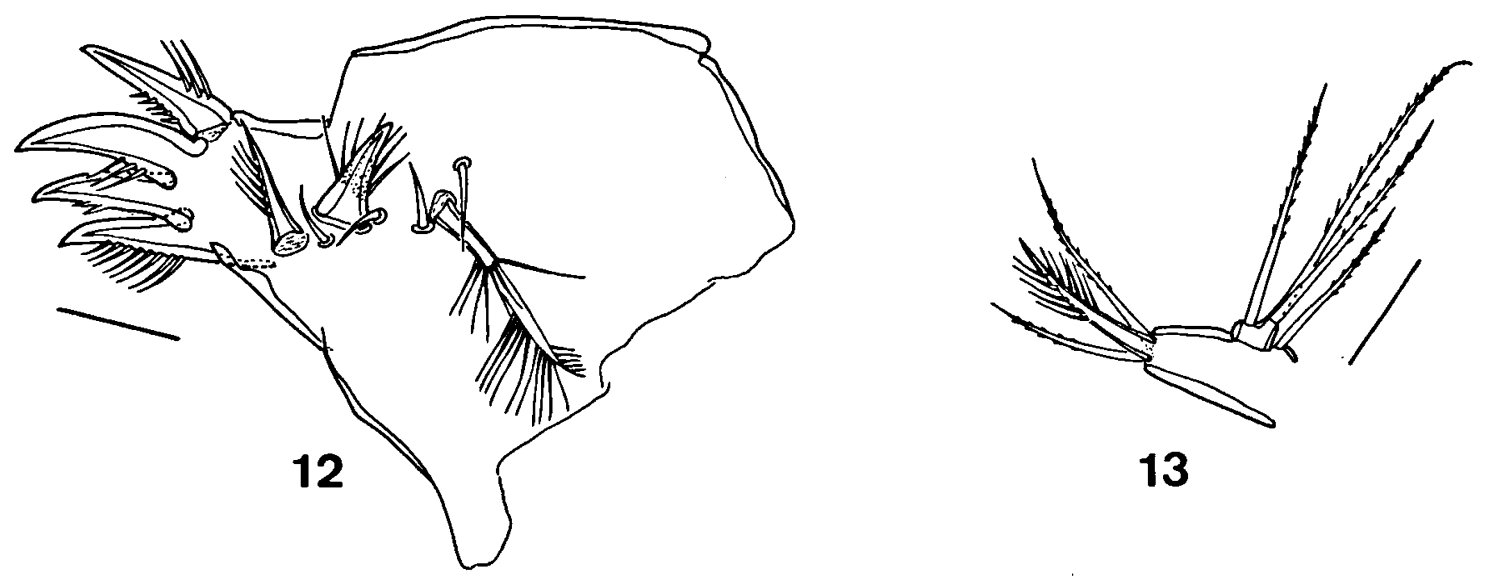

13
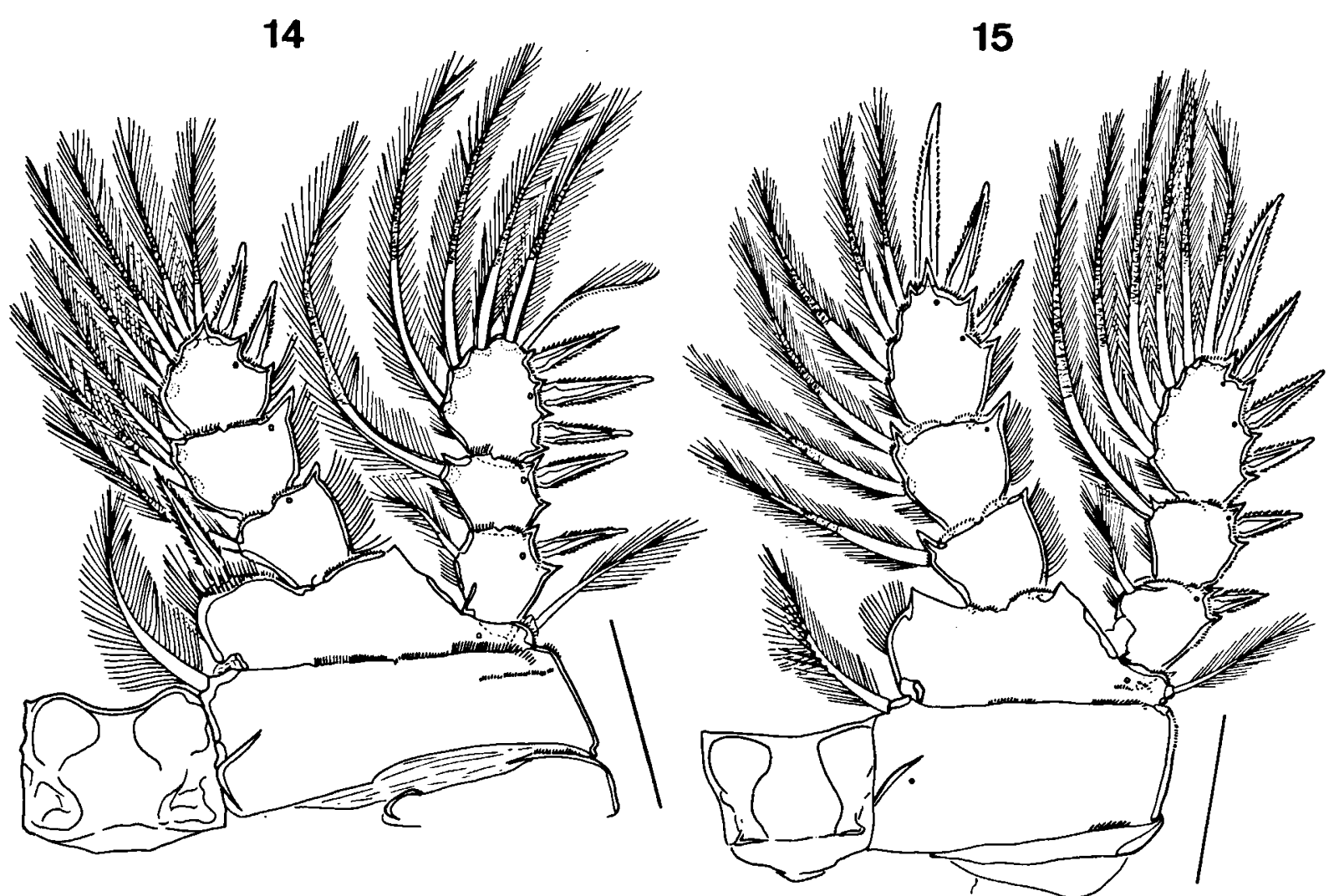

Figs. 12-15. Neocyclops (Protoneocyclops) ferrarii sp. n., ९ : 12, maxillular praecoxa, inner; 13, maxillular palp; 14, leg 1, anterior; 15, leg 3, anterior. Scale bars $20 \mu \mathrm{m}$ (Figs. 12-13), $50 \mu \mathrm{m}$ (Figs. 14-15).

Integumental pore pattern on anterior surface of legs 1, 3 (identical to leg 2) and 4 as in Figs. 14-16. Leg 4 exopodite segment 3 (Fig. 16) with all inner setae modified, plumose proximally and with finely serrate hyaline membrane distally. Leg 4 endopodite segments 2 and 3 fused, row of tiny spinules on frontal surface indicating lost articulation between segments. Terminal endopodal segment of leg 4 

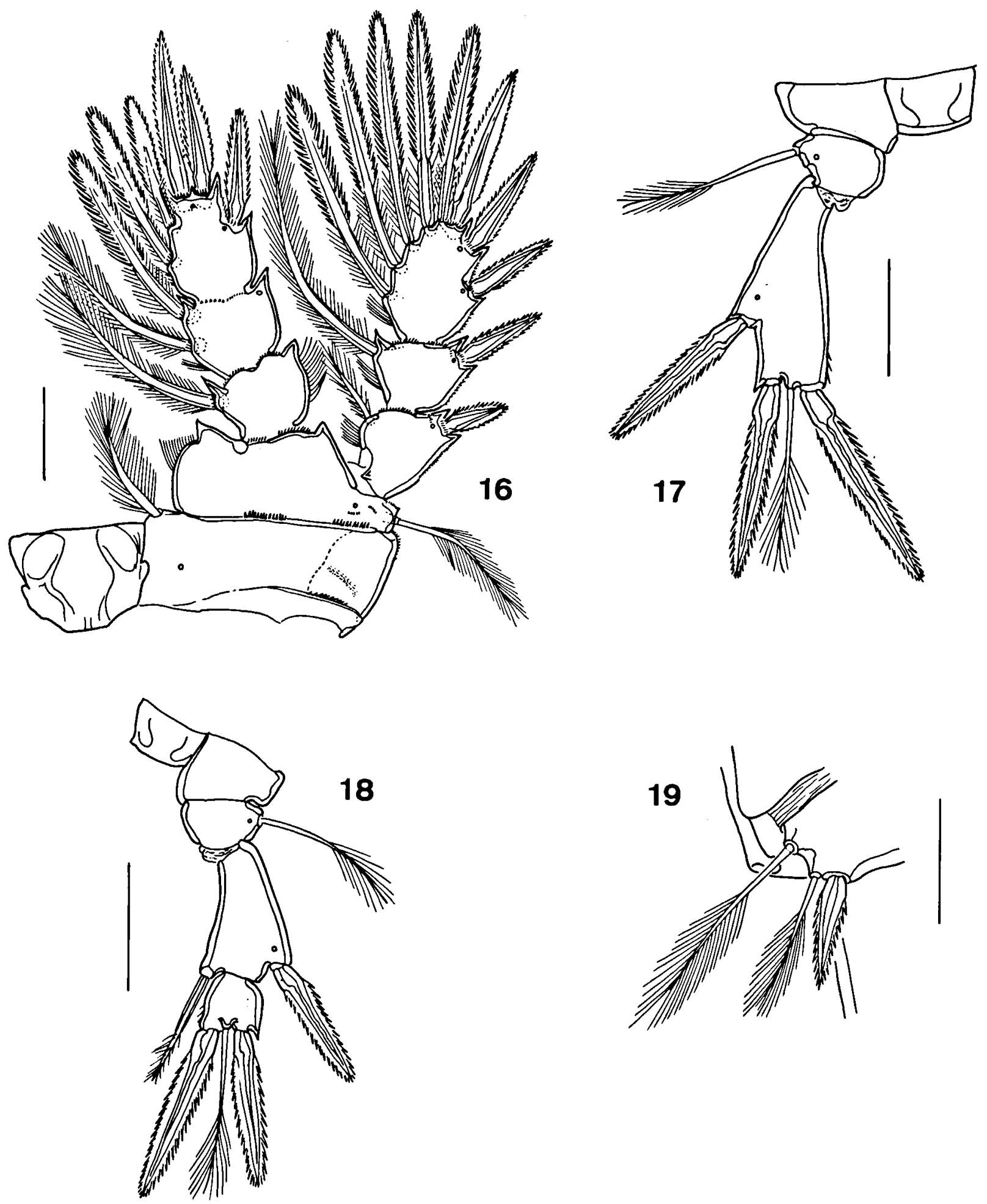

Figs. 16-19. Neocyclops (Protoneocyclops) ferrarii sp. n.: 16, o leg 4, anterior; 17, \& leg 5, anterior; 18, o leg 5, anterior; 19, or leg 6, anterior. Scale bars $30 \mu \mathrm{m}$. 
bearing 3 setae resembling those of exopodite segment 3, none of them reaching tip of outer apical spine of segment.

Leg 5 (Fig. 17) with intercoxal sclerite and consisting of 3 segments. Coxa unarmed. Basis with integumental pore on anterior surface near implantation of outer seta. Exopodite twice longer than wide, armed with 3 spines and 1 seta. Inner apical spine little longer than segment (1.08-1.12:1). Outer apical spine 1.12 times longer than lateral spine, both shorter than exopodite. Integumental pore on anterior surface near indentation of proximal spine.

Male: Body length 520 to $580 \mu \mathrm{m}(n=7)$. Prosome : urosome ratio $=1.07-1.36: 1$. Urosome with 6 somites. Caudal rami 2.2 times longer than broad $(n=5)$. Antennule of 16 segments; armature as illustrated by Lotufo \& Da Rocha (1993) for N. (N.) vicinus.

Leg 5 (Fig. 18) 4-segmented. Coxa and basis as in female. Exopodite segment 1 with outer spine and inner seta; segment 2 with one seta flanked by 2 spines.

Leg 6 (Fig. 19) consisting of inner spine and 2 setae; outer seta about 1.5 times length of middle seta.

The male is identical to the female in all other respects.

Etymology. - The species is named after Dr. Frank D. Ferrari, distinguished copepodologist at the National Museum of Natural History, Smithsonian Institution, Washington, and collector of the specimens.

Differential diagnosis. - The subgenus Protoneocyclops Petkovski, 1986 includes six species; $N$. $(P$.) mediterraneus (Kiefer, 1960); N. (P.) stocki Pesce, 1985; N. (P.) papuensis Fiers, 1986; $N$. (P.) wellsi Petkovski, 1986; N. (P.) herbsti Petkovski, 1986, and $N$. (P.) geltrudeae Pesce \& Galassi, 1993. The latter three species share with $N$. $(P$.) ferrarii the presence of a plumose seta at the inner corner of the proximal exopodal segment of the male leg 5; the remaining species bear a variably shaped spine at that position.
Neocyclops (P.) ferrarii can be easily distinguished from $N$. (P.) geltrudeae as the latter species is peculiar in the armature of legs 4 and 5 in both sexes, as well as in the relative lengths of the inner apical and dorsal setae of the caudal rami. The separation of $N$. (P.) ferrarii from $N$. (P.) wellsi and $N .(P$.$) herbsti is more difficult because of their$ more conservative morphology (Wells, 1967; Herbst, 1964). However, differences can be found in the length/width ratio of the caudal ramus, the relative lengths of inner and outer caudal apical setae, the seta representing the exopodite of the antenna, and the spines of leg 5 , and finally in the length and structure of the two distalmost inner setae on the endopodite of leg 4.

Neocyclops improvisus from Cuba still has an undefined subgeneric position since the male of this species is unknown. The specimens from Belize cannot be ascribed to this species as they have an antennule of 12 segments, caudal rami 3 times longer than wide, innermost apical caudal seta longer than outermost one, and distalmost inner seta of terminal endopodal segment of leg 4 shorter than middle seta.

\section{Remarks on the morphology of Neocyclops}

Until now, all Neocyclops species have been described as having the first pediger fused with the cephalosome. In fact this somite is free although reduced and often hidden under the cephalic shield (Fig. 2). Perhaps this is the reason for the lack of any reference in previous papers. When concealed beneath the cephalic shield the limits of the somite look like fine lines hardly discernible in specimens still having internal tissues. But its existence as a separate somite is uncontestable when the soft tissues are removed. If partially or totally exposed, it is possible to observe the attachment areas of the muscles of legs 1 on the tergal plate (Fig. 3). Specimens of Neocyclops (Neocyclops) vicinus and $N$. $(P$.) medius in the author's collection showed the same condition warranting the supposition that the free pediger 1 is a consistent feature of the genus. Rocha \& Iliffe (1994) considered this character state a plesiomorphy found only in Euryte and Troglocy- 

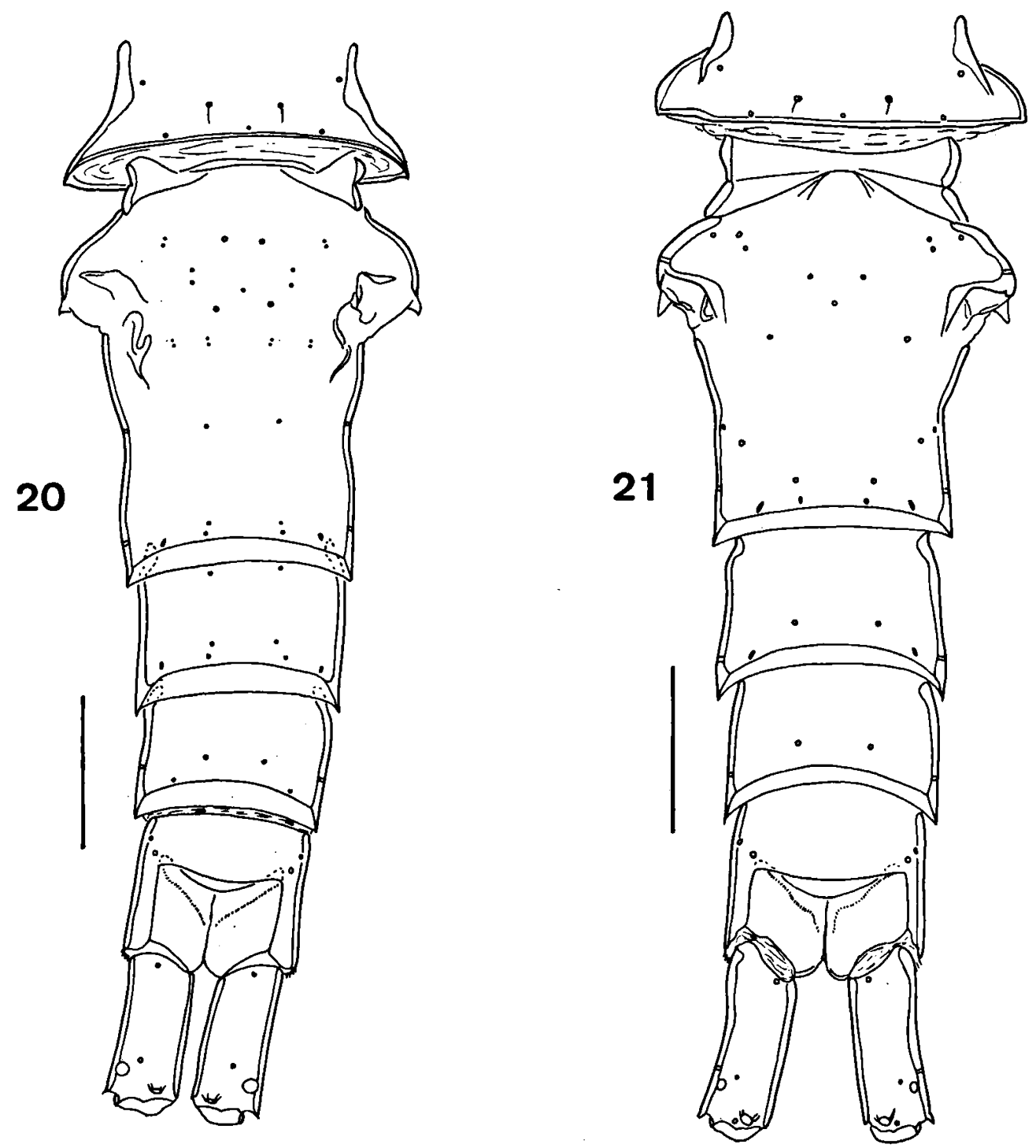

Fig. 20. Urosome of Neocyclops (Neocyclops) salinarum (Gurney, 1927) showing integumental pore pattern, dorsal.

Fig. 21. Urosome of Neocyclops (Neocyclops) vicinus (Herbst, 1955) showing integumental pore pattern, dorsal. Scale bars $50 \mu \mathrm{m}$.

clops, genera with the most ancestral character set within the Cyclopidae. Discovery of this feature in Neocyclops indicates its close relationship to these two marine genera.

Huys \& Boxshall (1991) pointed out the existence of a pair of transverse ducts connected to the copulatory duct of the female seminal receptacle, a novel structure found only in cyclopids. These ducts seem to be absent in $N$. (P.) ferrarii, which has a transverse cuticular thickening partially fused to the seminal receptacle and connected to the integument of the genital double somite by five attachment areas. Apparently this thickening supports the curved, tubular seminal receptacle. As the structure of the seminal receptacle is very conservative within the genus, it is here supposed that such thickening exists in all other species. If interspecific variations in shape and number of attachment areas of the thickening are known, it could be useful for separating Neocyclops species. 


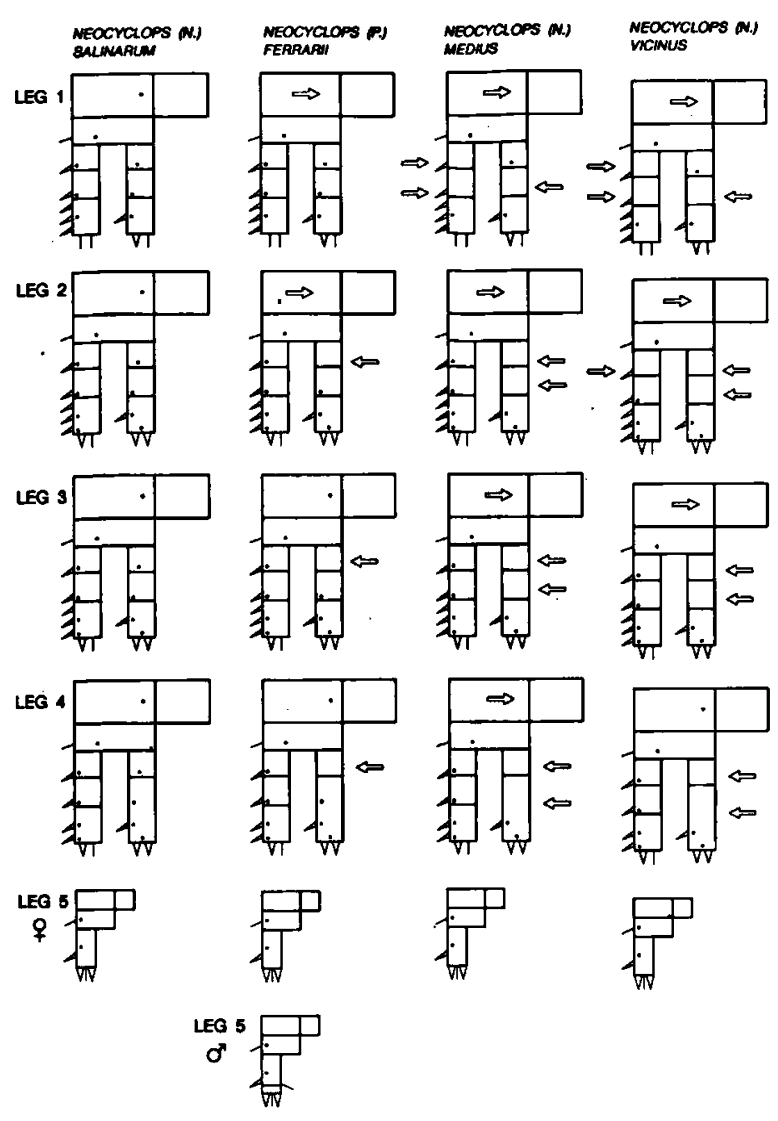

Fig. 22. Schematic comparison of integumental pore arrangement on the anterior surface of legs 1-5 of four species of Neocyclops. Pores present in Neocyclops (Neocyclops) salinarum but lacking in other species are indicated by arrows. The male leg 5 is illustrated only if differing from that of the female in number of segments and armature.

The great difficulty in studying the taxonomy of Neocyclops is the scarcity of diagnostic characters distinguishing species. Traditionally, distinctions between species have been based on the morphology of the caudal rami, segmentation of the antennule, armature of antenna and mandibular palp, and structure of legs 4 and 5, in some cases involving length ratios of the characters. The integumental pore pattern of the urosome could be helpful if known for a larger number of species than we know today. For instance, the patterns of the dorsal pores of the female urosome of Neocyclops (N.) salinarum (Gurney, 1927) and $N$. (N.) vicinus (Figs. 20-21) are provided here to be compared with that of $N$. (P.) ferrarii (Fig. 5). The pattern ob- served in $N$. (N.) salinarum differs significantly from those of the other two species, mainly in the genital double somite.

Cyclopid copepods have integumental pores on the anterior surface of legs 1 to 5. Originally there would have been a pore for each segment of the legs, except for the terminal segment of exopodite and endopodite of the legs 2 to 4 which bears two pores, arranged as in $N$. (N.) salinarum (Fig. 22). The coxal pore of legs 1 and 2 as well as the pore of the proximal segment of the endopodite of each of legs 2 to 4 are lacking in $N$. $(P$.) ferrarii. The number of pores is lower in $N$. (N.) medius and $N$. (N.) vicinus as illustrated in Fig. 22. The latter two species have similar pore numbers and position. These differences between four species suggest that the arrangement of the leg pores might also be useful in interpreting Neocyclops taxonomy.

\section{Acknowledgements}

The author is indebted to Dr. Frank D. Ferrari who kindly made available the material for this study. Thanks are due to Drs. Frank D. Ferrari and Janet L.W. Reid for reading and commenting on the manuscript.

\section{References}

Herbst, H.V., 1964. Cyclopoida Gnathostoma (Crustacea Copepoda) aus dem Litoral und Küstengrundwasser des Roten Meeres. Kieler Meeresforsch., 20 (Suppl.): 155-169.

Huys, R. \& G.A. Boxshall, 1991. Copepod evolution: 1-468 (Ray Society, London).

Lotufo, G.R. \& C.E.F. da Rocha, 1993. Neocyclops Gurney from Brazilian sandy beaches (Copepoda: Cyclopoida). Bijdr. Dierk., 63(3): 163-172.

Pesce, G.L., 1985. Amsterdam Expeditions to the West Indian Islands, Report 45. Cyclopids (Crustacea, Copepoda) from West Indian groundwater habitats. Bijdr. Dierk., 55(2): 295-323.

Pesce, G.L. \& D.P. Galassi, 1993. Amsterdam Expeditions to the West Indian Islands, Report 74. The genus Neocyclops Gurney in the West Indies: an update including the description of Neocyclops (Protoneocyclops) geltrudeae n. sp. Bijdr. Dierk., 63(2): 115-120.

Petkovski, T.K., 1986. Zur Taxonomie des Genus Neocyclops Gurney, 1927 (Crustacea, Copepoda, Cyclopoida). Acta Mus. maced. Sci. nat., 18(2): 27-46. 
Pleşa, C., 1973. Un nouveau Cyclopide interstitiel de la mer des Caraibes: Neocyclops improvisus n. sp. (Crustacea, Copepoda). Résultats des Expéditions Biospéologiques cubanoroumaines à Cuba, 1: 119-122 (Ed. Acad. Rep. Soc. România).

Pleşa, C., 1981. Cyclopides (Crustacea, Copepoda) de Cuba. Résultats des Expéditions Biospéologiques cubano-roumaines à Cuba, 3: 17-34 (Ed. Acad. Rep. Soc. România).

Rocha, C.E.F. da \& T.M. Iliffe, 1994. Troglocyclops janstocki, new genus, new species, a very primitive cyclopid (Copepoda: Cyclopoida) from an anchialine cave in the Bahamas. Hydrobiologia, 292/293: 105-111.

Wells, J.B.J., 1967. The littoral Copepoda (Crustacea) of Inhaca Island, Mozambique. Trans. r. Soc. Edinburgh, 67(7): 189-358.

Received: 26 May 1994 